$$
\text { CONF-960944--9 }
$$

GA-A22452

\title{
FABRICATION DEVELOPMENT AND USAGE OF VANADIUM ALLOYS IN DIII-D
}

\author{
by \\ J.P. SMITH, W.R. JOHNSON, and E.E. REIS
}




\section{DISCLAIMER}

This report was prepared as an account of work sponsored by an agency of the United States Government. Neither the United States Government nor any agency thereof, nor any of their employees, makes any warranty, express or implied, or assumes any legal liability or responsibility for the accuracy, completeness, or usefulness of any information, apparatus, product, or process disclosed, or represents that its use would not infringe privately owned rights. Reference herein to any specific commercial product, process, or service by trade name, trademark, manufacturer, or otherwise, does not necessarily constitute or imply its endorsement, recommendation, or favoring by the United States Government or any agency thereof. The views and opinions of authors expressed herein do not necessarily state or reflect those of the United States Government or any agency thereof. 


\section{DISCLAIMER}

Portions of this document may be illegible in electronic image products. Images are produced from the best available original document. 


\title{
FABRICATION DEVELOPMENT AND USAGE OF VANADIUM ALLOYS IN DIII-D
}

\author{
by \\ J.P. SMITH, W.R. JOHNSON, and E.E. REIS
}

This is a preprint of a paper to be presented at the 19th Symposium on Fusion Technology, September 16-20, 1996, Lisbon, Portugal and to be published in the proceedings.

\author{
Work supported by \\ the U.S. Department of Energy \\ under Contract No. DE-AC03-89ER51114 \\ and General Atomics IR\&D Funds
}




\title{
Fabrication Development and Usage of Vanadium Alloys in DIII-D
}

\author{
J.P. Smith, W.R. Johnson, E.E. Reis \\ General Atomics, P.O. Box 85608, San Diego, California 92186-5608, USA
}

General Atomics is procuring material, designing components, and developing fabrication techniques for the use of vanadium alloy into the DIII-D divertor as elements of the Radiative Divertor Project modification. This program was developed to assist in the development of low activation alloys for fusion use by demonstrating the fabrication and installation of vanadium alloy components in an operating tokamak. Along with fabrication development, the program includes multiple steps starting with small coupons installed in DIII-D to measure the environmental effects on vanadium. This program is being implemented in collaboration with the Department of Energy (DOE) Fusion Materials Program, particularly efforts at Argonne National Laboratory (ANL) and Oak Ridge National Laboratory (ORNL).

Procurement of the material for this program has been completed. The world's largest heat of vanadium alloy, $1200 \mathrm{~kg}$ of $\mathrm{V}-4 \mathrm{Cr}-4 \mathrm{Ti}$ alloy, has been produced and converted into various product forms. A description of the manufacturing process is presented and results of the chemistry are reported.

As part of the program, research into potential fabrication methods is being performed. Joining of vanadium alloys was identified as the most critical fabrication issue for its use in the Radiative Divertor Program. Successful welding trials have been performed using resistance, friction and electron beam methods. Metallography and mechanical tests have been used to evaluate the welds and results are presented.

\section{INTRODUCTION}

The environmental benefits of fusion energy can be great if and when low activation materials are utilized. Development of low activation materials has been in progress around the world for many years and many materials have been considered and evaluated for irradiation performance. In the U.S., the primary work on low activation materials has been performed under the auspices of the Fusion Materials Program of the Department of Energy's Office of Fusion Energy Sciences. Vanadium alloys have been identified as the leading fusion structural material based on their high temperature capability and irradiation performance (stability). The alloy $\mathrm{V}-4 \mathrm{Cr}-4 \mathrm{Ti}$ has been selected by the U.S. program as the primary candidate vanadium alloy. The chrome and titanium additions improve strength and irradiation stability over pure banadium. While vanadium is a fairly common element, it is primarily used as a minor alloying element in steels and not as a base metal for alloys. Outside the fusion program, the uniqueness of vanadium's characteristics have not found other uses, thus the development of the alloys has proceeded only within the limited resources of the fusion program. The production and fabrication of vanadium alloys has been primarily limited to small research heats $(<100 \mathrm{~kg})$ to study alloy composition effect on properties and irradiation stability with no development of components. The largest lot of vanadium alloy produced in the U.S. before the present effort was a $500 \mathrm{~kg}$ heat of $\mathrm{V}-4 \mathrm{Cr}$ 4Ti [1]. To date, no significant components have been made from vanadium alloys. Welding of vanadium alloys is difficult due to the pick-up of impurities at high temperature and subsequent embrittlement. Welding has been limited to development efforts primarily for looking at the irradiation stability of welds.

\section{VANADIUM IN DIII-D}

General Atomics, along with Argonne National Laboratory (ANL) and Oak Ridge National Laboratory (ORNL), has developed a plan utilizing vanadium alloys in the DIII-D tokamak for the purpose of enhancing the on-going research on low activation alloys [2]. This plan culminates in the fabrication, installation, and operation of a water 
cooled vanadium alloy structure as part of the DIII-D Radiative Divertor Program (RDP). The use of vanadium in DIII-D provides a meaningful step towards advancing development of low activation materials for fusion power applications by 1) demonstrating the in-service behavior of a vanadium alloy in a typical tokamak environment, and 2) developing knowledge and experience on design, processing, and fabrication of full-scale vanadium alloy components.

The design, manufacture, and installation of a vanadium private flux baffle structure for the upper divertor of the RDP represents the culmination of the vanadium alloy program (Fig. 1). The structure consists of toroidally-continuous, water-cooled structural panels with mechanically attached graphite tiles making up the plasma facing surface. The panels will be water cooled during tokamak operations, experiencing a maximum temperature of $\sim 60^{\circ} \mathrm{C}$, but during baking of the vacuum vessel, hot air replaces the water for baking to $400^{\circ} \mathrm{C}$. Due to the lower electrical resistivity of the $\mathrm{V}-4 \mathrm{Cr}-4 \mathrm{Ti}$ alloy compared to Inconel 625 , the toroidal current flow during plasma disruptions will be approximately 4 times larger than in similar Inconel RDP components. The design of the panels and supports account for these larger loads.

Each water cooled ring will be made in six segments, with the segments fabricated by welding two $4.8 \mathrm{~mm}$ sheets creating an internal coolant channel. Resistance seam welds will provide the shear strength between the two sheets and a

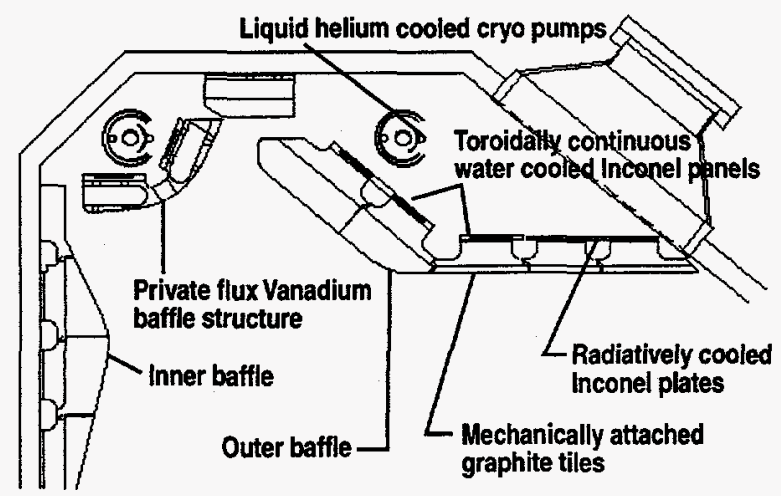

Fig. 1. Location of vanadium structure in radiative divertor. perimeter electron beam weld makes the vacuum seal. Friction welding methods are proposed for attaching studs to the panels to attach the graphite tiles. To facilitate installation, bi-metallic tube joints are planned so that all field welds will be Inconel to Inconel.

\section{PRODUCTION OF VANADIUM ALLOY}

A heat of vanadium alloy has been produced for the fabrication of the RDP components. In preparation for the production, a detailed material specification for $\mathrm{V}-4 \mathrm{Cr}-4 \mathrm{Ti}$ alloy was written by General Atomics with assistance from Teledyne Wah Chang Albany, ANL and ORNL. From the starting material to completion of product forms, the specification outlined the production steps along with control and quality tests required. Goals for the levels of impurities were specified, with a focus on keeping the levels of potentially embrittling elements $(\mathrm{O}, \mathrm{N}, \mathrm{C}$, etc.) low. Consideration was also given to minimizing the levels of long lived neutron activation impurities, $\mathrm{Nb}, \mathrm{Mo}, \mathrm{Ag}$. In the future, low levels of these elements will be required to achieve low activation properties for the material.

Material processing started in September 1995 with the selection of raw vanadium lots (derbies) to be electron beam melted into pure vanadium ingots. Two ingots were electron beam melted; one $(\sim 900 \mathrm{~kg})$ and the other $(\sim 1000 \mathrm{~kg})$. Samples were taken from the two ingots for chemical analysis and for rolling by ORNL into sheet and machining into Charpy V-notch specimens by ANL. Impact testing at $-196^{\circ} \mathrm{C}$ was performed to evaluate the fracture behavior of the vanadium. The data agreed reasonably with test results for previous pure vanadium ingots. The entire $900 \mathrm{~kg}$ ingot was chipped and blended with $400 \mathrm{~kg}$ of the second ingot. The consolidation of the vanadium along with high purity chromium and double vacuum melted titanium proceeded in February 1996. The ingot was vacuum arc melted twice to form a $1200 \mathrm{~kg} \mathrm{~V}-4 \mathrm{Cr}-4 \mathrm{Ti}$ ingot. The ingot outside diameter was machined, cut into two pieces, and vacuum canned in stainless steel for extrusion into sheet bar. The material was extruded into $\sim 11.4 \mathrm{~cm} \times 24.1 \mathrm{~cm}$. sheet bar at $1150^{\circ} \mathrm{C}$.

The next step in the processing was the warm rolling of the extrusion into $4.8 \mathrm{~mm}$ plate and 
machining and swaging into $10 \mathrm{~mm}$ diameter rod. The sheet bar was longitudinally warm rolled to a thickness of $4.57 \mathrm{~cm}$ and then cut into $\sim 59 \mathrm{~cm}$ long sections. The pieces were cross rolled to $4.8 \mathrm{~mm}$ thick plate, $59 \times 170 \mathrm{~cm}$. The warm work of the material was limited to $15 \%$ reduction per pass and $50 \%$ reduction between vacuum anneals at $1050^{\circ} \mathrm{C}$. The rod is presently being manufactured by using the $4.57 \mathrm{~cm}$ plate, sawing it into rectangular bars, and machining the bars into rounds. Subsequent swaging will yield $1 \mathrm{~cm}$ diameter rod. Again the reduction is being limited to $50 \%$ between anneals.

\section{WELDING DEVELOPMENT}

A key goal of the DIII-D vanadium program is to develop manufacturing techniques. The U.S. vanadium program has been primarily focused upon alloy development and irradiation properties with little work being performed on developing manufacturing techniques or processes. The advent of making components has required research be initiated on fabrication techniques, and in particular, welding. Vanadium, being a refractory metal, is highly susceptible to pick-up and embrittlement by oxygen, nitrogen, carbon, and hydrogen at elevated temperatures, and most welding, therefore, has required a high purity protective environment. Welding studies using gas tungsten arc, e-beam, and laser weld processes are ongoing at ANL and ORNL, but additional processes are required for the DIII-D program. Thus, studies have been initiated on resistance, friction, and electron beam welding of vanadium alloys.

\subsection{Resistance Welding}

Resistance welding is planned for structurally joining the two halves of vanadium water cooled panels together for the RDP. It will not provide the vacuum-tight weld, however. Resistance welding was chosen as the joining method, placing the weld on the neutral axis of the part, thus potentially minimizing weld distortion. It was also thought that the high pressures necessary to create the weld would help to exclude the embrittling elements. Initial spot welding trials made in air produced a weld nugget with microhardness only $10 \%$ greater than the bulk material. This was a very promising result, indicating that a protective atmosphere may not be required. A parameter search of pressure and current for welds of thicker material was started. No weld nugget was initially achieved on $3.8 \mathrm{~mm}$ sheet, based on parameters for welding Inconel, although the developed diffusion bond demonstrated considerable strength (up to $135 \mathrm{MPa}$ ) in shear tests. Additional trials were made using higher power inputs. These trials were successful, forming weld nuggets approximately $7 \mathrm{~mm}$ in diameter. Micro-hardness measurements again showed $<10 \%$ increase in hardness. Using parameters based on data for welding carbon steel, a material with similar resistivity and strength, spot weld trials were then performed on $4.8 \mathrm{~mm}$ thick vanadium material and were also successful. The strength of these spot welds was evaluated in single spot lap shear tests with strengths measured up to $685 \mathrm{MPa}$. These welds had slight porosity in the center, which further testing has eliminated. Resistance seam welding trials are now planned.

\subsection{Friction Welding Studies}

Two types of friction welding trials are in progress. Inertia and portable friction welding will be used for joining vanadium alloy to itself, and inertia welding for creating a bi-metallic joint. The first inertia weld trials of vanadium rod to vanadium plate were successful in air, without any protective environment. It is believed that the high pressure used in the process, coupled with the fact that the process is really a hot forging method with the material never reaching a melting point, excludes potentially embrittling elements and minimizes brittle inner metallic formations. Metallographic examination revealed complete bonding with no indications of porosity or cracking. The interface had a fine grain structure, with little or no grain growth. Microhardness measurements showed only slight increases in hardness in the weld and heat affected zones (HAZ). Tensile and torsion tests resulted in failures in the parent material away from the joint and HAZ.

A bi-metallic joint was considered essential to allow for field welding of Inconel components in DIII-D with all vanadium welds carefully characterized in the shop. Inertia welding was considered a good candidate process for a bi-metallic joint because melting of the materials does not occur, 
minimizing the chance of brittle intermetallic phase formations. After several attempts, trials using different diameter rods for the two materials, to match their forgeabilities, were successful. Metallography showed complete bonding with no porosity or cracking in the joint. Tensile pull tests were performed on three weld trial samples. Two samples failed in the Inconel 625 section well away from the weld area (at -930 MPa stress) and one sample failed at the approximate weld interface, at a stress level of $\sim 760 \mathrm{MPa}$. With the joining ability of the two materials demonstrated, the development was shifted to creating a bi-metallic tube joint. The initial trial samples were encouraging but not leak tight and had varying strengths ( $70-380 \mathrm{MPa})$. There was significant bonding at the interface, but also a considerable amount of fine porosity. It was determined from metallography, that there was radial displacement of vanadium material at the joint which released some forging pressure. New trials with a different joint configuration have been made and are being evaluated.

Preliminary portable friction welding trials of rod to plate have been performed to develop methods of in-situ replacement of studs on the water cooled panels. The initial trials achieved substantial bonding but the hardness of the weld interface increased significantly. In addition, extensive grain growth occurred at the interface and HAZ. It was noted in the trials that the temperature of the interface was significantly higher than in the inertia weld process, and the time to create the weld was longer. It was believed that both of these factors led to the grain growth and increase in hardness. Additional trials are in progress.

\subsection{Electron Beam Welding Studies}

Preliminary electron beam welding trials have also been initiated at General Atomics to complement the work being performed at ORNL. Initial weld parameters were obtained from ORNL [3] and weld penetration tests were performed using $6.35 \mathrm{~mm}$ thick vanadium alloy plate. These trials established specific weld parameters for creating a lap weld of two $3.85 \mathrm{~mm}$ thick vanadium alloy sheets. The lap weld, once created, was metalurgical examined. Good weld penetration was obtained with no indications of cracking or porosity. Microhardness measurements showed less than $10 \%$ increase in hardness. A weld was made in a single sheet to produce three tensile specimens to develop strength data on the weld. The tensile specimens all failed in the parent material well away from the weld joint and $\mathrm{HAZ}$ at values equal to the ultimate strength of the material.

\section{CONCLUSIONS}

A program for utilizing vanadium alloys in DIII-D has been developed to enhance the development of low activation vanadium alloys for fusion. The production of $1200 \mathrm{~kg}$ of $\mathrm{V}-4 \mathrm{Cr}-4 \mathrm{Ti}$ alloy for this program is nearly complete. Two vanadium ingots have been electron beam melted as base materials for the vanadium alloy ingot. The alloy ingot has been double vacuum arc melted and extruded into sheet bar. Warm rolling the material into $4.8 \mathrm{~mm}$ sheet has been completed. Successes have been achieved in making vanadium alloy welds using various methods including resistance, friction, and electron beam welding.

\section{ACKNOWLEDGMENTS}

This is a report of work supported by General Atomics internal $R \& D$ funding and the U.S. Department of Energy under Contract No. DEAC03-89ER51114. The authors would like to acknowledge the efforts of Teledyne Wah Chang Albany for their efforts producing the vanadium alloy material, KT Aerofab for resistance welding, Interface Welding for inertia welding work, and to RAM Stud for friction welding work.

\section{REFERENCES}

1. H.M. Chung, et al., Report, DOE/ER-0313/17, Oak Ridge National Laboratory, Oak Ridge, Tennessee (1994), p. 178.

2. J.P. Smith, et al., "Utilization of Vanadium Alloys in the DIII-D Radiative Divertor Program," to be published in Proc. of the 7th Intnl Conf. on Fusion Reactor Materials (ICFRM-7), Obninsk, Russia, September 25-29, 1995.

3. King, J., Oak Ridge National Laboratory, private communication. 